\title{
PENGARUH METODE LATIHAN DAN MOTIVASI BERPRESTASI TERHADAP KETERAMPILAN MENGGIRING BOLA PADA PERMAINAN SEPAK BOLA
}

\author{
${ }^{1}$ Ferdi Zulkarnain \& ${ }^{2}$ Aridhotul Haqiyah \\ e-mail: ferdizul39@yahoo.co.id \\ ${ }^{1}$ Universitas Nahdlatul Ulama Lampung
}

Jl. Hanafiah Lintas Timur, Mataram Marga, Lampung Timur

${ }^{2}$ Universitas Islam 45 Bekasi

\section{Jl. Cut Meutia No. 83 Bekasi}

\begin{abstract}
Abstrak: Latar belakang dilakukannya penelitian ini adalah kurangnya pembinaan olahraga khususnya cabang olahraga sepak bola yang belum maksimal, masih perlu adanya pelatihan tentang teknik-teknik yang ada di dalam sepak bola kepada setiap siswa agar mampu menguasai sepak bola dengan benar. Tujuan dari penelitian ini adalah untuk mengetahui pengaruh manakah yang lebih efektif antara bentuk metode latihan padat dan distribusi terhadap keterampilan menggiring bola jika dikaitkan dengan faktor motivasi berprestasi pada Siswa SMK N Way Bungur, Lampung Timur. Metode yang digunakan dalam penelitian ini adalah metode eksperimen dengan desain treatment by level $2 \times 2$. Penelitian ini dilaksanakan di SMK N Way Bungur, Lampung Timur pada November - Desember 2016 dengan populasi siswa ekstrakurikuler sepak bola yang berjumlah 110 orang. Teknik pengambilan sampel dalam penelitian ini adalah random sampling. Sampel dalam penelitian ini berjumlah 60 orang. Instrumen yang digunakan dalam penelitian ini adalah tes keterampilan menggiring bola. Hasil penelitian ini membuktikan terjadinya pengaruh antara metode latihan dan motivasi berprestasi terhadap keterampilan menggiring bola dalam permainan sepak bola.
\end{abstract}

Kata-kata kunci: latihan padat, latihan distribusi, motivasi berprestasi, keterampilan menggiring bola

\section{THE EFFECT OF TRAINING METHOD AND ACHIEVEMENT MOTIVATION TOWARD THE DRIBBLING SKILL IN FOOTBALL}

\begin{abstract}
The background of this research is the lack of sports coaching, especially the football sport who has not been maximized, there is a still need of training about the techniques that are in the football to every student so that they can master the football correctly. The purpose of this study was to find out which effect is more effective between the massed training method and distributed training method in the dribbling skill if it is associated with the achievement motivation factor of the students of SMK N 1 Way Bungur, East Lampung. The method used in this study was an experimental method. The design of the study was treatment design by level $2 \times 2$. This research was conducted at SMK N Way Bungur, East Lampung in November - December 2016 with 110 students of extracurricular soccer student population. The sampling technique in this research is random sampling. The sample in this study amounted to 60 people. The instrument used in this study is a dribbling skill test. The results of this study prove the influence between the method of exercise and achievement motivation of dribbling skills in the game of soccer.
\end{abstract}

Keywords: massed training, distributed training, achievement motivation, dribbling skill

\section{PENDAHULUAN}

Sepak bola merupakan salah satu cabang olahraga yang sangat digemari penduduk di seluruh dunia. Hal tersebut telah sesuai dengan kenyataan yang terjadi bahwa permainan sepak bola sekarang bertambah maju serta memiliki pengikut dan simpatisan paling banyak di dunia. Artinya, permainan ini dikenal dan dimainkan oleh hampir seluruh lapisan masyarakat mulai dari anak-anak, remaja maupun orang tua bahkan wanita pun menggemari dan memainkannya. Selain berorientasi pada prestasi, saat ini banyak kelompok dan klub sepak bola di masyarakat yang difungsikan sebagai wahana rekreasi, sehingga boleh dikatakan sepak bola merupakan olahraga yang sangat popular 
di masyarakat. Sepak bola merupakan olahraga yang mudah dimainkan dan murah dari sisi biaya dikarenakan tidak membutuhkan peralatan yang banyak dan mahal, cukup dengan bola sepak dan tiang gawang. Pada tingkat sekolah, olahraga sepak bola mempunyai tempat tersendiri yang begitu digemari oleh siswa dan siswi, hal ini terbukti sepak bola sudah menjadi bagian dari kurikulum Pendidikan Jasmani di tingkat sekolah baik sekolah dasar, menengah maupun atas.

Pembinaan cabang olahraga sepak bola dilakukan di jalur pendidikan formal maupun nonformal. Salah satu wujud pembinaan di jalur pendidikan formal adalah kegiatan ekstrakurikuler. Kegiatan ekstrakurikuler merupakan salah satu kegiatan yang berada di luar jam pelajaran, dalam hal ini kegiatan ekstrakurikuler bersifat tidak terbatas oleh waktu sehingga seorang guru, pelatih atau pembina bisa mengembangkan kegiatan secara menyeluruh dan terperinci. Melalui kegiatan tersebut, guru atau pelatih bisa lebih banyak dan leluasa menjelaskan mengenai kondisi fisik, teknik, taktik dan strategi serta peraturan-peraturan permainan sepak bola. Faktor yang paling penting dalam mempengaruhi prestasi cabang sepak bola adalah kondisi fisik, persiapan teknik, kesiapan mental serta penguasaan strategi dalam bermain.

Prestasi belajar maupun prestasi latihan pada semua cabang olahraga tidak hanya ditentukan oleh kondisi fisik dan penguasaan teknik saja, tetapi juga banyak dipengaruhi oleh metode latihan, dan faktor psikologis. Dari hasil pengamatan penulis, di Sekolah Menengah Kejuruan (SMK) Negeri Way Bungur, Lampung Timur pada umumnya pembinaan cabang olahraga sepak bola masih belum maksimal. Dibuktikan dengan prestasi ekstrakurikuler SMKN Way Bungur yang masih minim di cabang olahraga sepak bola. Oleh karena itu, perlu dilakukan penelitian tentang pengaruh metode latihan dan motivasi berprestasi terhadap keterampilan menggiring bola.

Keterampilan menggiring bola merupakan salah satu teknik yang sangat besar peranannya dalam permainan sepak bola. Selama dalam permainan, sebagian besar pemainnya akan banyak mendribble atau menggiring bola. Kemampuan dalam menggiring bola akan sangat menentukan terhadap penguasaan bola dalam suatu pertandingan, maka semakin besar pula kemungkinan dapat memenangkan pertandingan.

Menggiring bola adalah salah satu teknik dasar bermain sepak bola yang memiliki unsur seni dan daya tarik tersendiri, jika dibandingkan dengan teknik dasar lainnya. Pada prinsipnya, menggiring bola merupakan cara menggulirkan bola ke depan secara terus menerus di atas tanah. Menurut Mielke (2007: 1), menggiring adalah keterampilan dasar dalam sepak bola karena semua pemain harus mampu menguasai bola saat sedang bergerak, berdiri atau bersiap melakukan operan atau tembakan. Menggiring adalah metode individual yang digunakan oleh para pemain sepak bola untuk bergerak dengan bola dari satu titik ke titik lainnya. Luxbacher (2012) juga berpendapat bahwa penggiringan bola dalam sepak bola memiliki fungsi yang sama dengan bola basket yaitu memungkinkan untuk mempertahankan bola saat berlari melintasi lawan atau maju ke ruang terbuka.

Dari pendapat di atas dapat disimpulkan bahwa menggiring bola merupakan teknik dalam usaha memindahkan bola dari satu daerah ke daerah lain pada saat permainan sedang berlangsung, maka dapat dirumuskan bahwa kemampuan menggiring bola merupakan gerakan lari sambil membawa bola dengan kaki, di mana bola didorong dengan bagian kaki agar terus bergulir terus di atas tanah.

Metode latihan padat diterjemahkan dari massed practice, yaitu istilah yang digunakan oleh Singer (1980: 124), bahwa yang dimaksud adalah melakukan latihan secara terus-menerus tanpa selang waktu istirahat. Latihan terus-menerus adalah latihan di mana jumlah atau lamanya waktu istirahat yang diberikan di sela-sela latihan sangat pendek atau tidak ada sama sekali, dengan kata lain, latihan tersebut secara relatif dilaksanakan terus-menerus.

Metode latihan padat dan metode latihan distribusi adalah dua jenis latihan yang memperhitungkan perbandingan waktu kerja dan istirahat. Oxendine (1982: 74) mengemukakan bahwa metode latihan padat adalah metode latihan yang hanya memiliki sedikit waktu istirahat di antara awal sampai akhir periode kegiatan, sedangkan metode latihan distribusi adalah latihan yang periode kerjanya dibagi-bagi oleh waktu istirahat, atau oleh kegiatan lain yang berbeda. Adanya waktu istirahat ini terkait dengan asam laktat dalam darah, di mana asam laktat dapat mempengaruhi secara langsung kerja otot dan penampilan atlet.

Berdasarkan teori di atas, yang dimaksud dengan metode latihan padat adalah perencanaan penyajian latihan yang disusun dengan menggunakan teknik melatih secara terus-menerus, atau teknik melatih dengan memberikan kegiatan-kegiatan yang harus diberikan secara berkesinambungan. Kesempatan untuk istirahat tetap diberikan, namun 
waktunya singkat bila dibandingkan dengan waktu yang diberikan untuk menyelesaikan tugas tersebut.

Metode latihan distribusi dapat diartikan dengan istilah distributed practice, yaitu istilah yang digunakan oleh Singer (1980: 85) untuk menyebut suatu bentuk kegiatan latihan yang dalam pelaksanaan kegiatan tersebut dibagi-bagi atau diselingi dengan beberapa kali waktu istirahat. Latihan terbagi sebagai suatu bentuk latihan. Latihan distribusi adalah suatu bentuk latihan di mana kegiatan latihan tersebut terbagi-bagi oleh sejumlah waktu istirahat, waktu yang dipergunakan untuk istirahat sama atau lebih lama dari pada waktu yang disediakan untuk melakukan satu bagian dari kegiatan latihan tersebut.

Magill dalam Schmidt (1986: 69) menjelaskan bahwa latihan distribusi (terbagi) sebagai suatu bentuk latihan di mana waktu istirahat yang diberikan di sela-sela kegiatan latihan cukup banyak. Schmidt mendefinisikan bahwa latihan distribusi adalah suatu bentuk latihan yang terbagi-bagi oleh sejumlah waktu istirahat. Berdasarkan beberapa teori tersebut, maka yang dimaksud dengan metode latihan distribusi adalah suatu kegiatan latihan yang terbagi-bagi dan diselingi waktu istirahat.

Dengan demikian yang dimaksud dalam penelitian ini adalah latihan yang disusun dengan menggunakan teknik membagi satu paket (tugas gerak) latihan menjadi beberapa bagian kegiatan.

Tabel 1

Perbedaan Metode Latihan Distribusi dan Metode Latihan Padat

\begin{tabular}{|c|c|c|}
\hline $\begin{array}{l}\text { Aspek yang } \\
\text { dilatih }\end{array}$ & $\begin{array}{c}\text { Metode latihan } \\
\text { distribusi }\end{array}$ & $\begin{array}{c}\text { Metode } \\
\text { latihan padat }\end{array}$ \\
\hline Fisiologis & Tidak melelahkan & Melelahkan \\
\hline Psikologis & $\begin{array}{l}\text { Dorongan berlatih } \\
\text { dengan baik } \\
\text { diberikan pada } \\
\text { waktuistirahat }\end{array}$ & $\begin{array}{l}\text { Dorongan berlatih } \\
\text { dengan baik diberikan } \\
\text { selama menyelesaikan } \\
\text { tugas gerak }\end{array}$ \\
\hline Kepelatihan & $\begin{array}{l}\text { Program latihan } \\
\text { jangka panjang }\end{array}$ & $\begin{array}{l}\text { Program latihan } \\
\text { jangka pendek }\end{array}$ \\
\hline $\begin{array}{l}\text { Waktu } \\
\text { pelaksanaan }\end{array}$ & $\begin{array}{l}\text { Dibutuhkan waktu } \\
\text { lama }\end{array}$ & $\begin{array}{l}\text { Dibutuhkan waktu } \\
\text { singkat }\end{array}$ \\
\hline $\begin{array}{l}\text { Kegiatan } \\
\text { latihan/ } \\
\text { pengulangan } \\
\text { tugas latihan }\end{array}$ & $\begin{array}{l}\text { Terpenggal-penggal } \\
\text { diselingi waktu } \\
\text { istirahat }\end{array}$ & $\begin{array}{l}\text { Terus-menerus tanpa } \\
\text { adanya waktu istirahat }\end{array}$ \\
\hline $\begin{array}{l}\text { Perbaikan } \\
\text { kesalahan gerak }\end{array}$ & $\begin{array}{l}\text { Diperbaiki pada } \\
\text { saat waktu istirahat }\end{array}$ & $\begin{array}{l}\text { Diperbaiki pada } \\
\text { kegiatan latihan } \\
\text { berlangsung }\end{array}$ \\
\hline
\end{tabular}

Motivasi berprestasi adalah suatu dorongan bagi seseorang untuk melakukan sesuatu yang terbaik, yang merupakan suatu prestasi yang diperbuat sehingga mengungguli atau melebihi suatu prestasi yang diperbuat serta biasa mengungguli prestasi yang didapat oleh orang lain. Keinginan seseorang untuk berprestasi setinggi-tingginya akan melahirkan motivasi berprestasi. Motivasi beprestasi bagi setiap siswa untuk memenuhi harapan yang dikehendakinya. Pencapaian prestasi dipandang sebagai fungsi dua karakteristik yaitu keterampilan dan kemauan kedua karakteristik tersebut merupakan satu kesatuan yang saling mendukung, karena dengan memiliki kemauan saja kesuksesan sulit dicapai tanpa didukung keterampilan yang memadai.

Heckhausen dalam Setyobroto (2001: 43) berpendapat bahwa motivasi berasal dari kata motif yakni sumber pendorong dan penggerak perbuatan manusia (Potential Motivation) sedangkan motivasi itu sendiri merupakan suatu proses aktualisasi dari sumber penggerak dan pendorong dari motif tersebut. Aliran psikologi sosial seperti McClelland dan Atkinson dalam Setyobroto (2001: 46) berpendapat bahwa motivasi dapat didasarkan pada tiga macam kebutuhan yakni kebutuhan untuk berprestasi (need for achievement), kebutuhan untuk berkuasa (need for power), dan kebutuhan untuk bergabung (need for affiliation).

Motivasi berprestasi dapat dilihat sebagai suatu proses dari dalam diri seseorang untuk melakukan suatu usaha dalam mencapai suatu tujuan tertentu. Motivasi berprestasi yang kuat menunjukkan bahwa dalam diri orang tersebut tertanam dorongan kuat untuk mencapai sesuatu. Dari pendapat tersebut dapat dijelaskan bahwa motivasi berprestasi adalah suatu dorongan yang berasal dari seseorang untuk mencapai tujuan yang diinginkan. Salah satu bentuk dorongan yang dilakukan individu dalam mencapai tujuan dan aktivitas disebut landasan motivasi berlatih yang kuat. Menurut McClelland ada setidaknya 6 aspek yang terkandung dalam motivasi berprestasi. Keenam aspek tersebut ialah (1) kreatif inovatif, (2) tanggung jawab, (3) umpan balik, (4) mempertimbangkan resiko, (5) keinginan menjadi yang terbaik, dan (6) waktu penyelesain tugas.

Dari uraian di atas, dapat disimpulkan bahwa motivasi berprestasi merupakan suatu dorongan, keinginan dan tingkat kesediaan seseorang untuk mengeluarkan upaya dalam rangka mencapai prestasi terbaik. Dalam hal ini, tinggi rendahnya motivasi berprestasi dapat dilihat dari aspek-aspek yang telah dijelaskan di atas. 


\section{METODE PENELITIAN}

Penelitian ini dilaksanakan pada bulan November - Desember 2016 di SMK N Way Bungur, Lampung Timur. Metode yang digunakan dalam penelitian ini adalah metode eksperimen dengan desain treatment by level $2 \times 2$. Desain treatment by level merupakan suatu tindakan terhadap satu variabel atau lebih yang dimanipulasi secara simultan agar dapat mempelajari pengaruh setiap variabel terhadap variabel terikat atau pengaruh yang diakibatkan adanya interaksi antara beberapa variabel. Rancangan faktorial adalah unit-unit eksperimen ke dalam sel sedemikian rupa secara acak, sehingga setiap unitunit eksperimen dalam setiap sel relatif homogen. Secara rinci, rancangan desain treatment by level $2 \times 2$ penelitian dapat dilihat pada tabel berikut.

Tabel 2

Desain Treatment by Level $2 \times 2$

\begin{tabular}{ccc}
\hline \multirow{2}{*}{$\begin{array}{c}\text { Motivasi } \\
\text { berprestasi }(\mathrm{B})\end{array}$} & $\begin{array}{c}\text { Madat } \\
\left(\mathrm{A}_{1}\right)\end{array}$ & $\begin{array}{c}\text { Distribusi } \\
\left(\mathrm{A}_{2}\right)\end{array}$ \\
\hline $\begin{array}{c}\text { Motivasi } \\
\text { berprestasi } \\
\text { tinggi }\left(\mathrm{B}_{1}\right)\end{array}$ & $\mathrm{A}_{1} \mathrm{~B}_{1}$ & $\mathrm{~A}_{2} \mathrm{~B}_{1}$ \\
$\begin{array}{c}\text { Motivasi } \\
\text { berprestasi } \\
\text { rendah }\left(\mathrm{B}_{2}\right)\end{array}$ & $\mathrm{A}_{1} \mathrm{~B}_{2}$ & \\
\hline
\end{tabular}

Populasi dalam penelitian ini adalah siswa ekstrakurikuler SMK N Way Bungur, Lampung Timur yang berjumlah 110 siswa. Teknik pengambilan sampel dalam penelitian ini adalah random sampling. Dari 110 siswa SMK N Way Bungur, Lampung Timur tersebut diberi tes motivasi berprestasi dengan menggunakan kuesioner. Skor yang diperoleh dari pengukuran tersebut kemudian diranking dari nilai tertinggi ke rendah. Selanjutnya dimarching untuk menentukan kelompok yang dilatih dengan metode latihan padat $\left(\mathrm{A}_{1}\right)$ dan kelompok yang dilatih dengan metode latihan distribusi $\left(\mathrm{A}_{2}\right)$ berdasarkan tingkat motivasinya.

Untuk menentukan pembagian tingkat motivasi berprestasi, maka Verducci (2008: 175-176) menjelaskan yaitu $27 \%$ dari sampel diklasifikasikan siswa kelompok atas (tertinggi) dan $27 \%$ dari sampel diklasifikasikan siswa kelompok bawah (terendah) dengan mengabaikan di tengah-tengahnya yang digunakan sebagai unit analisis. Dari konsep tersebut digunakan sebagai rujukan untuk menentukan tingkat motivasi berprestasi anggota sampel sehingga jumlah sampel dari masing-masing tingkat motivasi berprestasi yaitu kelompok siswa yang memiliki motivasi berprestasi tinggi $\left(\mathrm{B}_{1}\right)$ adalah $27 \%$ dari $110=$ 29,7 atau 30 sampel dan kelompok siswa yang memiliki motivasi berprestasi rendah $\left(\mathrm{B}_{2}\right)$ adalah $27 \%$ dari 110 $=29,7$ atau 30 sampel. Sampel yang memenuhi syarat berjumlah 60 siswa dibagi menjadi empat kelompok, sehingga masing-masing kelompok memiliki 15 sampel. Deskripsi pengelompokkan sampel perlakuan sebagaimana tercantum dalam tabel 3 berikut.

Tabel 3

Pengelompokkan Subjek Penelitian

\begin{tabular}{lcc}
\hline & \multicolumn{2}{c}{ Metode latihan $(\mathrm{A})$} \\
\cline { 2 - 3 } Motivasi berprestasi $(\mathrm{B})$ & $\begin{array}{c}\text { Padat } \\
\left(\mathrm{A}_{1}\right)\end{array}$ & $\begin{array}{c}\text { Distribusi } \\
\left(\mathrm{A}_{2}\right)\end{array}$ \\
\hline $\begin{array}{l}\text { Motivasi berprestasi } \\
\text { tinggi }\left(\mathrm{B}_{1}\right)\end{array}$ & 15 & 15 \\
$\begin{array}{l}\text { Motivasi berprestasi } \\
\text { rendah }\left(\mathrm{B}_{2}\right)\end{array}$ & 15 & 15 \\
\hline Keseluruhan & 30 & 30 \\
\hline
\end{tabular}

Penelitian ini dilaksanakan di lapangan SMK N Way Bungur Lampung Timur, selama 17 kali pertemuan. Rancangan harus sesuai dengan asumsi penelitian, yaitu perlakuan terhadap sampel sama. Rancangan tersebut meliputi (1) lamanya latihan secara keseluruhan dalam penelitian ini 17 kali pertemuan. Latihan akan memberikan efek setelah enam minggu dan akan terlihat perubahan keterampilan teknik menggiring bola pada permainan sepak bola apabila dilakukan selama 3 kali pertemuan dalam seminggu, (2) banyaknya latihan secara keseluruhan dalam penelitian ini dilaksanakan 3 kali dalam seminggu, hal ini disesuaikan dengan jadwal latihan ekstrakurikuler SMK N Way Bungur, (3) lamanya latihan dalam seminggu adalah 60 menit untuk latihan inti. Setiap pertemuan masing-masing kelompok membutuhkan waktu untuk pemanasan 15 menit, latihan inti 60 menit, dan penutup 15 menit.

Instrumen motivasi berprestasi adalah skor instrumen yang diperoleh dari angket dengan beberapa indikator, diantaranya (1) tanggung jawab; (2) menyukai tantangan; (3) umpan balik; (4) kreatif dan inovatif; (5) menyelesaikan tugas dengan baik; dan (6) berasa unggul.

\section{HASIL DAN PEMBAHASAN}

\section{Hasil}

Sampel dalam penelitian siswa SMK N Way Bungur, Lampung Timur sebanyak 60 orang. Untuk pengolahan data analisis jalur, peneliti menggunakan SPSS versi 17 (Kadir, 2015: 261-269). Hasil perhitungan 
statistik deskriptif dapat dilihat pada tabel berikut.

Tabel 5

Hasil Penghitungan Statistik Deskriptif

Descriptive Statistics

Dependent Variable: Keterampilan Menggiring Bola

\begin{tabular}{lllcc}
\hline \multicolumn{1}{c}{$\begin{array}{c}\text { Metode } \\
\text { latihan }\end{array}$} & \multicolumn{1}{c}{$\begin{array}{c}\text { Motivasi } \\
\text { berprestasi }\end{array}$} & Mean & $\begin{array}{c}\text { Std. } \\
\text { deviation }\end{array}$ & $\mathrm{N}$ \\
\hline $\begin{array}{l}\text { Metode latihan } \\
\text { padat }\end{array}$ & $\begin{array}{l}\text { Motivasi berprestasi } \\
\text { tinggi }\end{array}$ & 13.87 & 1.060 & 15 \\
& $\begin{array}{l}\text { Motivasi berprestasi } \\
\text { rendah }\end{array}$ & 9.13 & 1.060 & 15 \\
\hline & Total & 11.50 & 2.623 & 30 \\
\hline $\begin{array}{l}\text { Metode latihan } \\
\text { distribusi }\end{array}$ & $\begin{array}{l}\text { Motivasi berprestasi } \\
\text { tinggi }\end{array}$ & 9.53 & 1.187 & 15 \\
& $\begin{array}{l}\text { Motivasi berprestasi } \\
\text { rendah }\end{array}$ & 12.27 & 1.163 & 15 \\
\hline Total & 10.90 & 1.807 & 30 \\
\hline Total & $\begin{array}{l}\text { Motivasi berprestasi } \\
\text { tinggi }\end{array}$ & 11.70 & 2.466 & 30 \\
& $\begin{array}{l}\text { Motivasi berprestasi } \\
\text { rendah }\end{array}$ & 10.70 & 1.932 & 30 \\
\hline & Total & 11.20 & 2.253 & 60 \\
\hline
\end{tabular}

Sebelum dilakukan analisis varian (Anava), terlebih dahulu dilakukan uji persyaratan analisis, yaitu (1) uji normalitas; dan (2) uji homogenitas populasi. Adapun hasilnya adalah sebagai berikut.

Tabel 6

Ringkasan Uji Normalitas Data

Tests of Normality

\begin{tabular}{lcccccc}
\hline & \multicolumn{3}{c}{ Kolmogorov-Smirnov $^{\mathrm{a}}$} & \multicolumn{3}{c}{ Shapiro-Wilk } \\
\cline { 2 - 7 } & Statistic & $\mathrm{df}$ & Sig. & Statistic & $\mathrm{df}$ & Sig. \\
\hline $\mathrm{A}_{1} \mathrm{~B}_{1}$ & 0.217 & 15 & 0.056 & 0.862 & 15 & 0.026 \\
$\mathrm{~A}_{2} \mathrm{~B}_{1}$ & 0.209 & 15 & 0.076 & 0.908 & 15 & 0.126 \\
$\mathrm{~A}_{1} \mathrm{~B}_{2}$ & 0.207 & 15 & 0.084 & 0.891 & 15 & 0.070 \\
$\mathrm{~A}_{2} \mathrm{~B}_{2}$ & 0.193 & 15 & 0.137 & 0.927 & 15 & 0.246 \\
\hline
\end{tabular}

a. Lilliefors significance correction

*. This is a lower bound of the true significance.

Karena signifikansi seluruh variabel lebih besar dari 0,05 maka dapat disimpulkan bahwa semua data penelitian berdistribusi normal.

Tabel 7

Hasil Penghitungan Uji Homogenitas Data

Test of Homogeneity of Variances

Keterampilan Menggiring Bola

\begin{tabular}{cccc}
\hline Levene statistic & df1 & df2 & Sig. \\
\hline 0.145 & 3 & 56 & 0.932 \\
\hline
\end{tabular}

Berdasarkan analisis pada tabel Test of Homogeneity of Variances diperoleh $\mathrm{F}=0,145$; df1= 3, df2=56, dan p-value $=0,932>0,05$ atau $\mathrm{H}_{0}$ diterima. Dengan demikian, data keterampilan menggiring bola dari keempat kelompok homogen.

\section{Pengujian hipotesis}

Berdasarkan hasil penghitungan uji hipotesis, keempat hipotesis yang diajukan adalah terbukti.
Adapun rangkumannya sebagai berikut.

Tabel 8

Rangkuman Penghitungan Uji Hipotesis

\begin{tabular}{lccc}
\hline Hipotesis yang diuji & $\begin{array}{c}\mathrm{F} \\
\text { hitung }\end{array}$ & p-value & Ket. \\
\hline $\mathrm{H}_{1}: \mu \mathrm{A}_{1}>\mu \mathrm{A}_{2}$ & 4,312 & 0,042 & Sig \\
$\mathrm{H}_{1}:$ Interaksi A X B $\neq 0$ & 166,935 & 0,000 & Sig \\
\hline Hipotesis yang diuji & $\begin{array}{c}\text { Mean } \\
\text { different }\end{array}$ & p-value & Ket. \\
\hline $\mathrm{H}_{1}: \mu \mathrm{A}_{1} \mathrm{~B}_{1}>\mu \mathrm{A}_{2} \mathrm{~B}_{1}$ & 4,333 & 0,000 & Sig \\
$\mathrm{H}_{1}: \mu \mathrm{A}_{1} \mathrm{~B}_{2}<\mu \mathrm{A}_{2} \mathrm{~B}_{2}$ & $-3,133$ & 0,000 & Sig \\
\hline
\end{tabular}

\section{Pembahasan}

Perbedaan keterampilan menggiring bola $(\mathrm{Y})$ antara siswa yang dilatih dengan metode latihan padat (A) dan siswa yang dilatih dengan metode latihan distribusi $\left(\mathrm{A}_{2}\right)$

Berdasarkan data hasil penelitian, terdapat perbedaan nilai rata-rata skor keterampilan menggiring bola dalam penerapan metode latihan padat dan metode latihan distribusi. Pada metode latihan padat diperoleh nilai rata-rata lebih besar, yaitu 11,50 jika dibandingkan dengan nilai rata-rata metode latihan distribusi, yaitu 10,90. Dari hasil perhitungan uji turkey pada hipotesis pertama diperoleh nilai sig = $0,000<0,05$, atau $\mathrm{H}_{0}$ ditolak. Hal ini berarti terdapat perbedaan rata-rata keterampilan menggiring bola antara siswa yang dilatih dengan metode latihan padat maupun metode latihan distribusi. Jika dibandingkan dengan metode latihan distribusi, maka metode latihan padat memberikan hasil yang lebih baik dalam meningkatkan keterampilan menggiring bola. Sesuai uraian dan pembahasan tentang keunggulan metode latihan padat dan metode latihan distribusi, maka secara keseluruhan metode latihan padat lebih baik daripada metode latihan distribusi dalam meningkatkan keterampilan menggiring bola pada siswa. Hal ini dikarenakan keunggulan dari latihan padat yang hanya memiliki sedikit waktu istirahat diantara awal sampai akhir periode kegiatan (Oxendine, 1982: 74). Adanya waktu istirahat ini terkait dengan asam laktat dalam darah, di mana asam laktat dapat mempengaruhi secara langsung kerja otot dan penampilan atlet.

Terdapat interaksi antara metode latihan (A) dan motivasi berprestasi (B) terhadap keterampilan menggiring bola ( $\mathrm{Y})$

Desain faktorial dalam penelitian memberikan kemungkinan kepada peneliti untuk menilai interaksi antara kedua variabel bebas, yaitu pengaruh yang berbeda dari salah satu diantara kedua variabel pada 
tingkat yang berbeda dari variabel lainnya. Berkaitan dengan variabel interaksi, hasil pengujian hipotesis menunjukkan bahwa terdapat interaksi antara metode latihan dan motivasi berprestasi terhadap keterampilan menggiring bola dengan nilai Sig $=0,000$ $<0,05$, atau $\mathrm{H}_{0}$ ditolak. Hal ini berarti ada pengaruh interaksi yang sangat signifikan antara faktor $\mathrm{A}$ (metode latihan) dan faktor B (motivasi berprestasi) terhadap keterampilan siswa dalam menggiring bola. Tampak dari hasil analisis bahwa besar pengaruh metode latihan dan motivasi berprestasi terhadap keterampilan menggiring bola sebesar 76,6\%. Wujud interaksi yang ditunjukkan oleh hasil perhitungan ini memberikan alasan yang jelas bahwa dengan keragaman karakteristik dan motivasi berprestasi siswa akan berdampak pada pemilihan metode latihan yang tepat. Motivasi berprestasi merupakan salah satu kondisi internal yang sangat berpengaruh terhadap pencapaian keterampilan yang dipelajari. Oleh karena itu, tingkat motivasi berprestasi saling mempengaruhi dengan metode latihan yang digunakan. Motivasi berprestasi merupakan pendorong perilaku individu untuk memenuhi kebutuhan berprestasi. Masalah kebutuhan individu merupakan dasar yang menimbulkan perbedaan tingkah laku individu, dimana individu bertingkah karena adanya dorongan untuk memenuhi kebutuhan (Tangkudung, 2012: 21). Individu yang memiliki motivasi berprestasi tinggi akan memiliki usaha yang sangat kuat untuk mencapai hasil sebaik- baiknya.

Dengan demikian antara metode latihan dan motivasi berprestasi akan saling mempengaruhi dalam meningkatkan keterampilan menggiring bola siswa. Hal ini sesuai dengan hasil penelitian Marwan (2009) bahwa terdapat perbedaan pengaruh antara dua metode latihan dengan motivasi berprestasi, maka terdapat interaksi antara metode latihan dan motivasi berprestasi terhadap keterampilan bola voli. Penelitian selanjutnya dilakukan oleh Wahyudin dan Haqiyah (2017) dengan kesimpulan bahwa terdapat interaksi antara latihan beban dan motivasi berprestasi. Dapat disimpulkan bahwa faktor latihan dapat berinteraksi dengan motivasi, baik motivasi berprestasi maupun motivasi belajar (Ponidin, 2017) dapat dijadikan sebagai variabel moderator dalam penelitian eksperimen.

Perbedaan keterampilan menggiring bola (Y) antara siswa yang dilatih dengan metode latihan padat (A1) dan siswa yang dilatih dengan metode latihan distribusi (A2) pada kelompok siswa yang memiliki motivasi berprestasi yang tinggi (B1)

Pada tingkat motivasi berprestasi tinggi dengan metode latihan padat, diperoleh nilai rata-rata siswa dalam menggiring bola sebesar 13,87 yang berarti lebih tinggi dari nilai rata-rata siswa dengan metode latihan distribusi, yaitu 9,53. Berdasarkan uji Turkey diketahui bahwa perbedaan keterampilan menggiring bola $(\mathrm{Y})$ antara siswa yang dilatih dengan metode latihan padat $\left(A_{1}\right)$ dan siswa yang dilatih dengan metode latihan distribusi $\left(\mathrm{A}_{2}\right)$ pada kelompok siswa yang memiliki motivasi berprestasi yang tinggi $\left(B_{1}\right)$. Pengujian simple effect untuk $\mathrm{B}_{1}$ : $\left(\mathrm{A}_{1} \mathrm{~B}_{1}-\mathrm{A}_{2} \mathrm{~B}_{1}\right)$ mempunyai nilai $\operatorname{sig} 0,000<0,05$ sehingga $\mathrm{H}_{0}$ ditolak. Artinya rata-rata hasil keterampilan menggiring bola kelompok siswa yang dilatih dengan metode latihan padat lebih tinggi daripada kelompok siswa yang dilatih dengan metode latihan distribusi pada siswa yang memiliki motivasi berprestasi tinggi. Perbedaannya (mean difference) sebesar 4,333. Hal ini membuktikan hipotesis alternatif $\mathrm{H}_{1}: \mu \mathrm{A}_{1} \mathrm{~B}_{1}>\mu \mathrm{A}_{2} \mathrm{~B}_{1}$ yang berarti bahwa siswa yang memiliki motivasi berprestasi tinggi dengan diberikan metode latihan padat akan memiliki keterampilan menggiring bola yang lebih baik daripada dilatih dengan metode latihan distribusi. Hal ini dikarenakan penyajian latihan yang disusun dengan menggunakan teknik melatih secara terus-menerus, melelahkan dan dorongan berlatih yang baik diberikan pada saat berlatih. Kesempatan untuk istirahat tetap diberikan, namun waktunya singkat bila dibandingkan dengan waktu yang diberikan untuk menyelesaikan tugas tersebut. Ciri dari metode latihan padat memberi rangsangan kepada siswa yang memiliki motivasi berprestasi tinggi untuk mengaktualisasikan diri, bertanggung jawab, dan memiliki keinginan yang kuat untuk menjadi yang terbaik. Siswa yang memiliki motivasi berprestasi tinggi akan menjadi landasan motivasi berlatih yang kuat, sehingga metode latihan padat merangsang keterampilan menggiring bola yang lebih baik daripada metode latihan distribusi.

Perbedaan keterampilan menggiring bola (Y) antara siswa yang dilatih dengan metode latihan padat $\left(A_{1}\right)$ dan siswa yang dilatih dengan metode latihan distribusi $\left(\mathrm{A}_{2}\right)$ pada kelompok siswa yang memiliki motivasi berprestasi yang rendah $\left(\mathrm{B}_{2}\right)$

Pada tingkat motivasi berprestasi yang rendah siswa yang dilatih dengan metode latihan padat, diperoleh nilai rata-rata siswa dalam keterampilan menggiring bola sebesar 9,13 yang berarti lebih rendah dari nilai rata-rata siswa yang dilatih dengan metode latihan distribusi, yaitu 12,27. Berdasarkan uji Turkey diketahui bahwa perbedaan keterampilan menggiring bola ( $Y$ ) antara siswa yang dilatih dengan metode latihan padat $\left(\mathrm{A}_{1}\right)$ dan siswa yang dilatih dengan metode latihan distribusi $\left(A_{2}\right)$ pada 
kelompok siswa yang memiliki motivasi berprestasi yang rendah $\left(B_{2}\right)$. Pengujian simple effect untuk $B_{2}$ : $\left(A_{1} B_{2}-A_{2} B_{2}\right)$ mempunyai nilai sig $0,000<0,05$ sehingga $\mathrm{H}_{0}$ ditolak. Hasil keterampilan menggiring bola kelompok siswa yang dilatih dengan metode latihan distribusi lebih tinggi daripada kelompok siswa yang dilatih dengan metode latihan padat pada siswa yang memiliki motivasi belajar rendah. Perbedaannya (mean difference) sebesar -3,133. Hal ini membuktikan hipotesis alternatif $\mathrm{H}_{1}: \mu \mathrm{A}_{1} \mathrm{~B}_{2}<\mu \mathrm{A}_{2} \mathrm{~B}_{2}$ yang berarti bahwa siswa yang memiliki motivasi berprestasi rendah akan memiliki keterampilan menggiring bola yang lebih baik jika dilatih dengan metode latihan distribusi daripada dengan metode latihan padat. Hal ini juga berkenaan dengan beberapa aspek yang mendasari perbedaan antara metode latihan padat dan metode latihan distribusi. Ciri metode latihan distribusi adalah tidak melelahkan, dorongan berlatih dengan baik diberikan pada waktu istirahat, program latihan jangka panjang, dibutuhkan waktu lama, terpenggal-penggal diselingi waktu istirahat, dan diperbaiki pada saat waktu istirahat. Siswa yang memiliki motivasi berprestasi rendah akan menjadi landasan motivasi berlatih yang rendah, sehingga metode latihan distribusi lebih tepat diberikan kepada siswa yang memiliki motivasi berprestasi rendah.

\section{PENUTUP}

\section{Kesimpulan}

Berdasarkan hasil penelitian dan pengujian hipotesis, maka dapat disimpulkan (1) secara keseluruhan terdapat perbedaan keterampilan menggiring bola $(\mathrm{Y})$ antara siswa yang dilatih dengan metode latihan padat $\left(\mathrm{A}_{1}\right)$ dan siswa yang dilatih dengan metode latihan distribusi $\left(\mathrm{A}_{2}\right) ;(2)$ terdapat interaksi antara metode latihan (A) dan motivasi berprestasi (B) terhadap kemampuan menggiring bola (Y); (3) terdapat perbedaan keterampilan menggiring bola (Y) antara siswa yang dilatih dengan metode latihan padat $\left(\mathrm{A}_{1}\right)$ dan siswa yang dilatih dengan metode latihan distribusi $\left(\mathrm{A}_{2}\right)$ pada kelompok siswa yang memiliki motivasi berprestasi yang tinggi $\left(\mathrm{B}_{1}\right)$. Bagi kelompok siswa yang memiliki tingkat motivasi berprestasi tinggi $\left(\mathrm{B}_{1}\right)$, keterampilan menggiring bola (Y) lebih tinggi bila dilatih dengan metode latihan padat $\left(\mathrm{A}_{1}\right)$; dan (4) terdapat perbedaan keterampilan menggiring bola ( $\mathrm{Y}$ ) antara siswa yang dilatih dengan metode latihan padat $\left(\mathrm{A}_{1}\right)$ dan siswa yang dilatih dengan metode latihan distribusi $\left(\mathrm{A}_{2}\right)$ pada kelompok siswa yang memiliki motivasi berprestasi yang rendah $\left(\mathrm{B}_{2}\right)$. Bagi kelompok siswa yang memiliki tingkat motivasi berprestasi rendah $\left(\mathrm{B}_{2}\right)$, keterampilan menggiring bola $(\mathrm{Y})$ lebih tinggi dilatih dengan metode latihan distribusi $\left(\mathrm{A}_{2}\right)$.

\section{Saran}

Berdasarkan kesimpulan dan implikasi penelitian, maka saran dari hasil penelitian ini adalah sebagai berikut (1) bagi guru Penjas dan pelatih, perlu menerapkan dan mengembangkan berbagai macam bentuk metode latihan, serta membuat pengelompokan kemampuan tiap variabel yang dimanipulasi agar menghasilkan prestasi maupun keterampilan yang baik; dan (2) perlu dilakukan penelitian lebih lanjut untuk mendapatkan gambaran yang lebih lengkap tentang faktor-faktor yang mempengaruhi kemampuan menggiring bola dalam permainan sepak bola selain variabel yang diteliti.

\section{DAFTAR PUSTAKA}

Kadir. (2015). Statistika terapan. Jakarta: Rajawali Pers. Luxbacher, Joseph A. (2012). Sepak bola. Depok: PT. Rajagrafindo Persada.

Marwan, Iis. (2009). Pengaruh metode latihan distribusi, latihan padat dan motivasi berprestasi terhadap keterampilan bola voli. Forum Kependidikan, 28 (2), 119-126.

Muhamad, Memet., \& Aridhotul Haqiyah. (2015). Diktat statistik pendidikan. FKIP: UNISMA Bekasi.

Muhamad, Memet., \& Aridhotul Haqiyah. (2015). Diktat statistik olahraga. FKIP: UNISMA Bekasi.

Mielke, Danny. (2007). Dasar-dasar sepak bola. Bandung: Pakar Raya.

Oxendine, B. Joseph. (1982). Psychology of motor learning. New Jersey: Prentice-Hall, Inc.

Ponidin, Aridhotul Haqiyah, dan DN Riyadi. (2017). Pengaruh gaya mengajar dan motivasi belajar terhadap keterampilan servis atas bola voli. Perspektif Ilmu Pendidikan, 31 (1), 13-20.

Schmidt, A. Richard. (1986). Motor skill. New York: Harper \& Row Publisher.

Setyobroto, Sudibyo. (2001). Psikologi olahraga suatu pengantar. Jakarta: P. Solo.

Singer, Robert N. (1980). Motor learning \& hu-man performance. New York: Mc Millan.

Tangkudung, James. (2012). Kepelatihan olahraga. Jakarta: Cerdas Jaya.

Verducci, Frank M. (2008). Measurement concepts in physical education. St. Louis Missouri: Mosby Company.

Wahyudin, Irma, \& A Haqiyah. (2017). Pengaruh latihan beban antara squat, standing calf raise, dan motivasi berprestasi terhadap jumping smash bola voli. Motion: Journal Research of Physical Education, 8 (2), 223-238. 